\title{
Nursing professionals' knowledge regarding the management of waste produced in primary health care
}

\author{
Conhecimento de profissionais da Enfermagem sobre o gerenciamento de resíduos produzidos na atenção primária
} Conocimiento de profesionales de Enfermería sobre manejo de residuos producidos en atención primaria

\section{Matheus Costa Brandão Matos', Layze Braz de Oliveira", Artur Acelino Francisco Luz Nunes Queiroz", Álvaro Francisco Lopes Sousa"l,III, Andreia Rodrigues Moura da Costa Valle', Denise de Andrade", Maria Eliete Batista Moura'}

\author{
' Universidade Federal do Piauí, Department of Nursing. Teresina, Piauí, Brazil. \\ "Universidade de São Paulo, Ribeirão Preto College of Nursing. Ribeirão Preto, São Paulo, Brazil. \\ III Universidade NOVA de Lisboa, Institute of Hygiene and Tropical Medicine. Lisboa, Portugal.
}

How to cite this article:

Matos MCB, Oliveira LB, Queiroz AAFLN, Sousa AFL, Valle ARMC, Andrade D, et al. Nursing professionals' knowledge regarding the management of waste produced in primary health care. Rev Bras Enferm [Internet]. 2018;71

(Suppl 6):2728-34. [Thematic Issue: Good practices in the care process as the centrality of the Nursing] DOI: http://dx.doi.org/10.1590/0034-7167-2018-0308

Submission: 05-09-2018Ａpproval: 06-13-2018

\begin{abstract}
Objective: To evaluate the knowledge of Nursing professionals regarding waste management in primary healthcare services. Method: Descriptive study with a mixed approach, developed with 42 nursing professionals who worked in basic health units of a capital in the Brazilian Northeast Region. Quantitative variables were analyzed by the SPSS 20.0 program. Reports were processed by the IRaMuTeQ software, analyzed according to the descending hierarchical classification, and grounded on the Collective Subject Discourse. Results: Low knowledge scores were obtained, associated with specific socioeconomic and training variables. Analysis of collected reports allowed to identify three classes: "Inadequate waste disposal: first and main step"; "Correct disposal improves service quality and prevents diseases"; and "Consequences associated with incorrect disposal". Conclusion: The knowledge of professionals falls short of the expectations to adequately manage waste produced in primary health care and is concentrated on the initial steps, mainly the disposal process.

Descriptors: Knowledge; Nurse Practitioners; Medical Waste; Primary Health Care; Occupational Health.
\end{abstract}

\section{RESUMO}

Objetivo: avaliar o conhecimento de profissionais da Enfermagem sobre o gerenciamento de resíduos de serviços de saúde produzidos na Atenção Primária. Método: estudo descritivo, de abordagem mista, desenvolvido com 42 profissionais de enfermagem integrantes de Unidades Básicas de Saúde de uma capital do Nordeste brasileiro. Variáveis quantitativas foram analisadas no software SPSS 20.0, enquanto depoimentos foram processados no IRaMuTeQ, analisados pela Classificação Hierárquica Descendente e fundamentados no Discurso do Sujeito Coletivo. Resultados: registraram-se baixos scores de conhecimento, associados a determinadas variáveis socioeconômicas e de formação. A partir dos depoimentos, foram identificadas três classes: "A disposição inadequada dos resíduos: primeiro e principal passo"; "O descarte correto melhora a qualidade do serviço e previne doenças" e "Consequências associadas ao descarte incorreto". Conclusão: O conhecimento dos profissionais mostrou-se aquém do necessário para um gerenciamento adequado dos resíduos produzidos na atenção primária e encontrou-se concentrado nas etapas iniciais, sobretudo o descarte.

Descritores: Conhecimento; Profissionais de Enfermagem; Resíduos de Serviços de Saúde; Atenção Primária à Saúde; Saúde Ocupacional.

\section{RESUMEN}

Objetivo: Evaluar el conocimiento de profesionales de Enfermería sobre manejo de residuos de servicios de salud producidos en Atención Primaria. Método: Estudio descriptivo de abordaje mixto, desarrollado con 42 profesionales de enfermería actuantes en Unidades Básicas de Salud de una capital del Noreste brasileño. Fueron analizadas las variables cuantitativas en software SPSS 20.0. Los testimonios fueron procesados utilizando IRaMuTeQ, analizados por Clasificación Jerárquica 
Descendente y fundamentados según Discurso del Sujeto Colectivo. Resultados: Se registraron bajos puntajes de conocimiento, asociados a determinadas variables socioeconómicas y de formación. A partir de los testimonios, fueron identificadas tres clases: "Disposición inadecuada de residuos: primer y principal paso"; "El descarte correcto mejora la calidad del servicio y previene enfermedades"; $y$ "Consecuencias asociadas al descarte incorrecto". Conclusión: El conocimiento de los profesionales es inferior al necesario para manejar adecuadamente los recursos producidos en atención primaria, se concentra en las etapas iniciales, especialmente en el descarte.

Descriptores: Conocimento; Enfermeras Practicantes; Residuos Sanitarios; Atención Primaria de Salud; Salud Laboral.

\section{CORRESPONDING AUTHOR Matheus Costa Brandão Matos}

E-mail: matheuscbmatos@gmail.com

\section{INTRODUCTION}

Production of healthcare waste (HCW) increased significantly in the past decades as a consequence of the growth of the population worldwide and the resulting higher demand for health services. This issue is even more critical in populous and developing countries, such as Brazil, given that inadequate waste management represents a potential risk for the population ${ }^{(1-3)}$.

To try to minimize this problem, the Brazilian government launched in 2010 the Brazilian Solid Waste Policy to establish principles, guidelines, standards, instruments, and objectives to manage waste originated in the country. One of its main recommendations is the requirement to develop and implement a Healthcare Waste Management Plan, which determines priority steps toward waste management ${ }^{(4)}$.

The phases related to the management of this type of waste include separation, identification, collection, internal and external transportation, temporary and external storage, treatment, and final disposal. These steps are indispensable and interdependent, although the absence of separation results in an inadequate waste destination, underused reusable materials, and increased risk of occupational accidents ${ }^{(1-3)}$.

The amount of produced HCW is directly proportional to the type of care offered. In Brazil, primary health care provides outpatient care in basic health units (BHUs). Although this healthcare level originates relatively small quantities of waste, the risk of harm associated with inefficient HCW management is considerable and real ${ }^{(1,5)}$.

The country has over 31 thousand $\mathrm{BHU}{ }^{(6)}$ which offer basic care to outpatients. These units generate a lower waste quantity in comparison with secondary and tertiary care, but their waste production equals that originated in hospitals, if all the active BHUs in the country are taken into consideration. Additionally, aspects inherent to this type of care, such as the characteristics of the produced waste and the negligence of professionals involved in questions related to occupational health, make this scenario even more serious ${ }^{(7)}$.

Among the various important specialties in primary health care, nursing plays a fundamental role in maintaining and promoting health to prevent harm to human beings. Therefore, ensuring the health of the environment is one of the attributions of these professionals. Although other healthcare professionals handle HCW for a significant amount of time, nursing teams perform care procedures that imply an increased risk of contamination by biological material, which involve the contact with sharps, bed linen, instruments, gauze compresses contaminated with blood or other secretions, and other objects.
Consequently, it is the professional class most exposed to the risk of biological accidents ${ }^{(8)}$.

\section{OBJECTIVE}

To evaluate the knowledge of nursing professionals regarding the management of HCW produced in primary health care.

\section{METHODS}

\section{Ethical aspects}

The present study was developed after its proposal approval by the research ethics committee. An alphanumeric identification system (NUR01 and TEC01) was used to keep the anonymity of the examined professionals.

The present investigation is part of the macroproject entitled "Infection prevention and control in healthcare services" carried out in a partnership between the Federal University of Piauí and the Ribeirão Preto College of Nursing at the University of São Paulo.

\section{Study design, setting, and period}

The present study was descriptive and cross-sectional, with a mixed concomitant approach, which allows collection and analysis of qualitative and quantitative variables simultaneously ${ }^{(9)}$. The study was conducted between June and September 2016 with nursing professionals who worked at family health strategy (FHS) in Teresina, capital of the state of Piauí, Brazil. The city has three regional health departments, which are the administrative instances between the health secretariat and BHUs, and two (South and East/Southeast) were selected to participate in the study. They encompassed 63 BHUs (27 in the South unit and 36 in the East/Southeast one). Data were collected in 21 BHUs, which were used as strata that gathered the primary analysis units (nursing professionals). The units were selected by draw, like in other studies ${ }^{(10)}$, and professionals were taken randomly from the set of workers available in a given unit in the shift during which data were collected, given that it was not possible to examine the totality of professionals.

\section{Population or sample; inclusion and exclusion criteria}

The sample was 42 nursing professionals, of whom 21 were technicians and 21 were nurses, selected through proportionate stratified random sampling. The inclusion criterion was to be a permanent nursing professional at a given $\mathrm{BHU}$ for at least a year. The exclusion criterion was to be a professional involved exclusively in administrative activities. 


\section{Study protocol}

Data were collected in a private room of the institutions by two trained researchers, guided by a semi-structured interview script tested previously and adapted from Mendes ${ }^{(11)}$, made up of three sections which explored the professionals' knowledge and daily practices related to HCW: (1) personal characteristics of professionals; (2) open-ended questions related to the definition, separation, destination, and handling of $\mathrm{HCW}$, and (3) multiple choice questions, in the format of a questionnaire, concerning the classification of the main types of waste produced in primary health care.

The interviews, which lasted 40 minutes on average, were recorded and transcribed. At the end of each interview the participants were asked about withdrawal or changes in the answers, but neither occurred.

\section{Results analysis and statistics}

The interview scripts were organized manually, double typed into the Microsoft Excel 2010 program, and imported to the SPSS for Windows version 20.0 software, which performed descriptive and univariate analyses. The chi-square test was used for categorical variables, with a level of significance of $p$ $\leq 0.05$ and a confidence interval of $95 \%$.

The reports of the participants were grouped into a corpus, which was statistically treated by the IRaMuTeQ program (acronym for Interface de $R$ pour les Analyses Multidimensionnelles de Textes et de Questionnaires) and analyzed according to the descending hierarchical classification (DHC), that is, taking into account the relationship between the classes as shown by the dendrogram ${ }^{(11-13)}$.

The next step was the identification of the keywords extracted from the reports of the interviewees, which complemented the findings of DHC and allowed to categorize the texts into "definitive classes". Analyses were based on the Collective Subject Discourse method.

The choice for these analysis methods allowed to obtain classes of excerpts which presented similar vocabulary based on the relationship between the classes exhibited by the dendrogram. These initial classes were named "pre-classes". At this point, the keywords were determined in the accounts of the participants to enrich the findings, with the theoretical background of the Collective Subject Discourse, which resulted in the delimitation of the excerpts in definitive classes.

The authors opted to keep the reports unchanged during transcription and include grammar mistakes, possible neologisms, and colloquialisms. In these cases, the expression was marked with an asterisk (*).

\section{RESULTS}

Among the nursing professionals who participated in the study, 35 (83.3\%) were women, $19(45.2 \%)$ graduated at least 15 years ago, and 20 (47.6\%) had been working at the FHS for at least ten years. Around half the interviewees (22 or $52.4 \%$ ) developed their activities exclusively in primary health care, and $15(35.7 \%)$ had at least one specialization in the health area.
The professionals were asked about the main materials used in primary health care and the ways to discard them. The general performance, expressed as the number of correct answers in the multiple-choice questions, was used in non-parametric statistical analyses (Table 1).

To compare the performance of the two professional groups, nurses and nurse technicians, regarding the questions addressing specific knowledge, the Mann-Whitney test was applied to the total score of each participant. The performance was inversely proportional to age, length of experience, and time since graduation (Table 2).

Table 1 - Performance of professionals (number of correct answers) in multiple-choice questions related to the classification of the main types of waste produced in primary health care, Teresina, Piauí, Brazil, 2016

\begin{tabular}{lcccc}
\hline Variables & $\begin{array}{c}\text { Obtained } \\
\text { interval }\end{array}$ & Median & $\overline{\mathrm{X}}(\mathrm{DP})$ & $\begin{array}{c}\boldsymbol{p} \\
\text { value* }\end{array}$ \\
\hline $\begin{array}{l}\text { Category Professional } \\
\quad \text { Nurse }\end{array}$ & $2-13$ & 4.0 & $5.3(2.9)$ & 0.308 \\
$\quad$ Nurse technician & $1-10$ & 5.0 & $5.4(1.8)$ & \\
$\quad \begin{array}{l}\text { Relationship } \\
\quad \text { FHS only }\end{array}$ & $2-9$ & 5.0 & $4.8(1.7)$ & 0.278 \\
$\quad$ FHS and other & $1-13$ & 5.5 & $5.8(2.8)$ & \\
\hline
\end{tabular}

Note: *Mann-Whitney test. FHS: Family Health Strategy. SD: standard deviation.

Table 2 - Correlation between the performance of professionals in multiplechoice questions related to the classification of the main types of waste produced in primary health care and the variables age, length of experience, and time since graduation, Teresina, Piauí, Brazil, 2016

\begin{tabular}{llccc}
\hline Variable & Age $^{* *}$ & $\begin{array}{c}\text { Length of } \\
\text { experience }\end{array} * * \begin{array}{c}\text { Time since } \\
\text { graduation** }\end{array}$ \\
\hline Performance & Correlation coefficient & -0.08 & -0.03 & -0.09 \\
& $p$ value* $^{*}$ & 0.59 & 0.81 & 0.53 \\
\hline
\end{tabular}

Note: *Mann-Whitney test. **Time in years.

A qualitative analysis was carried out using the IRaMuTeQ tool to complement the quantitative data. The starting point was 42 Initial Context Units (ICUs) and 192 Elementary Context Units (ECUs). The result was 5,412 occurrences, with a use of $68.9 \%$ of the originally processed corpus. Based on the $\mathrm{DHC}$, the text domains were identified and analyzed by isolating the most significant words and interpreting the meanings associated with them. These words were grouped into classes according to their meanings (Figure 1).

The corpus submitted to analysis by the program had elements which encompassed professional knowledge and practice related to HCW management in primary health care. The corpus was partitioned into two subgroups during data processing. The first one contained classes 1 and 2 and referred to HCW management, and its interfaces and involved steps. The second subgroup consisted of class 3 and included the two other classes, bringing an aspect of consequence associated with the inadequate HCW management. These findings are presented and justified according to the chosen theoretical framework. 


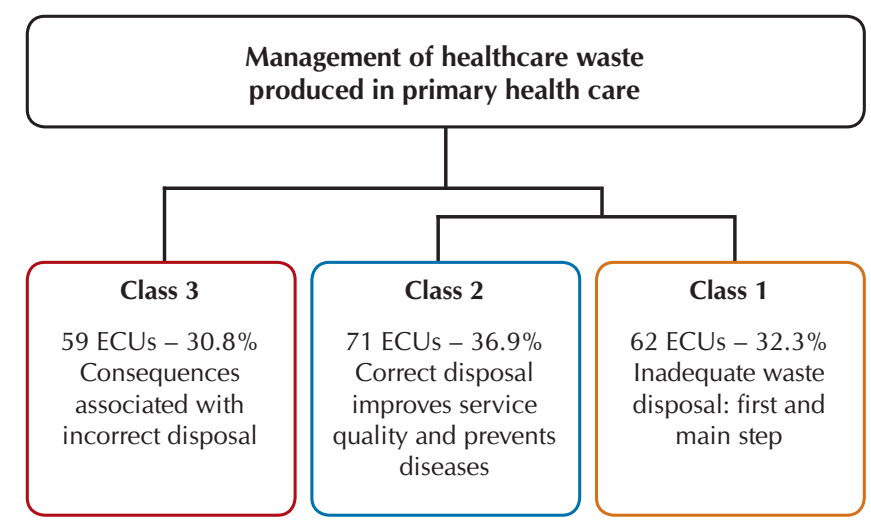

Note: ECU: Elementary context unit.

Figure 1 - Thematic structure of the knowledge of nursing professionals regarding management of $\mathrm{HCW}$ produced in primary health care, Teresina, Piauí, Brazil, 2016

\section{Class 1. Inadequate waste disposal: first and main step}

According to the reports, the interviewees consider that the process of HCW management begins with the correct separation of waste by the main producers, that is, healthcare professionals. However, this action is compromised by the negligence of some workers, who do not give materials the adequate destination out of inattention or sloppiness. This may result in crossed contamination and infection.

The problem is that everything goes to the same place, all together, gloves, cotton balls, syringes... Even needles. (TEC07)

It gets hard because if you do not know where to discard and do it the wrong way it gets complicated! Because you are passing something wrong to the next step. (TEC11)

Professionals have knowledge of the importance to separate this type of waste, but sloppiness and lack of care make them discard it carelessly just to save time. (NUR05)

Professionals pointed that in some sectors inadequate waste disposal is more noticeable and evident, such as vaccination rooms and users' homes. In the former, although the performed procedures present a low risk of infection, there is the possibility of exposure to biological material because of the handling of sharps and of contact with blood, secretions, and immunobiologicals.

In the vaccination room it is even worse [...]! It is all kept in a [common] open box under the counter, with open vaccine flasks, syringes, all together. (TEC04)

Here, especially in the vaccination room, the separation should be extremely important. (NUR12)

At users' homes, the situation is even more critical, given that professionals reported that it is not always possible to transport the material to the BHU to give it a proper destination, and the contaminated waste is discarded as common trash. Professionals stressed that they are not offered adequate transport conditions to move waste originated at users' homes, and that their transportation is also "adapted".
You change the catheter of the patient, and where does it go? To the patient's garbage! It is impossible to take it with us. (NUR03)

We guide the patient to discard it in their garbage with all the care in the world. (TEC18)

We have to go in this inadequate, tight car, that barely fits us, and what is more, take the garbage... (NUR07)

\section{Class 2. Correct disposal improves service quality and prevents diseases}

This class is complementary to class 1 and shows a variety of actions which aim at the correct HCW management. The reports of this class informed that professionals recognize primary healthcare activities, notably those carried out by nursing teams, as constant producers of a high quantity of waste. Workers from this sector were considered the main responsible for implementing the correct $\mathrm{HCW}$ management.

Bandages, catheterism, collection of capillary glucose... are activities that we do in each visit we pay to the community. (TEC03)

Vaccinate, collect material for exams, among many other things. These are activities in which nursing teams are directly involved and which originate waste, for sure! (NUR13)

For being aware of the potential primary health care has to produce waste, the participants stressed the need to work conjointly, aiming to reach a service level which prevents harm (represented by diseases and/or other damages in this context) to healthcare teams, patients, and communities.

\section{It facilitates and improves care when it is carried out [HCW} management] correctly. (NUR09)

It affects the quality and safety of the provided care positively, as long as it is performed correctly and at the right frequency. (TEC02)

When the adequate management is executed, professionals work to prevent infections of patients and physical space. (NUR15)

It has gotten to be integrated, everybody doing their share, but aware that results will come only if it is a conjoint target. (TEC06)

Among the several processes related to HCW management, professionals stressed the fundamental role of an adequate destination, which will enable separation and lead to the correct execution of subsequent steps. These reports reveal the need for a diagnosis suitable to identify flaws in the management, operation, and management infrastructure of HCW, thus enabling to develop and implement a HCW management plan.

The first step is the correct destination, which can be achieved by supervising teams while they separate waste. (NUR21) 
It is a ripple effect, if I put something in the correct place and the cleaning boy does his share, and the manager too, the waste will get at the final destination the way it should. (TEC14)

Actually, there should be a survey on the situation of the BHU, not just about this issue, but including it. (TEC09)

Professionals emphasized the low investments in human and financial sectors, which results in the exposure of some workers to vulnerability situations. They pointed the need for permanent education, mainly for cleaning teams, as well as investments in protection to employees (personal and collective protective equipment).

Actually, cleaning is carried out by outsourced staffs, with no training and no clue of the risks they take. (NUR04)

I have already seen a cleaning lady pounding the garbage to compact it and make it fit in her cart! I mean, total danger, there could be a needle there. (TEC12)

\section{Class 3. Consequences associated with incorrect disposal}

The interviews revealed the recognition that waste separation is the essential point of the discussion about HCW management. As observed in classes 1 and 2, inadequate waste separation has the potential to compromise posterior management steps. When this sequence of actions fails, there is an increased possibility of negative consequences for services and professionals, especially regarding occupational risks and operational costs with management.

It may lead to an accident in the future involving professionals, patients, or accompanying people. (TEC17)

Needles, blades, syringes... they leave them anywhere and someone may get hurt. (TEC21)

Here, for instance, is where blood sampling takes place and it is very dangerous, the lady had no descarpax* and cut herself because she did not remember she left the needle in the tub. (NUR17)

A concern with the community and the environment was identified, expressed as a reaction to the absence of adequate garbage collection in some neighborhoods and the fact that some patients who receive home care discard their waste in inadequate places, designed for domestic garbage.

During the visit it is very common to discard the waste in the regular garbage because there is no way to take the [sharps] box, but where does the patient take this waste? I do not know. (TEC16)

This is a poor community, I know that many people discard their garbage in landfills, and I wonder how that waste can spread and contaminate people. (NUR10)

Despite some conceptual difficulty, nursing professionals stressed the importance of an HCW management plan in addition to continuous training of healthcare professionals and cleaning staff to minimize risks to all people involved in waste handling.
It is necessary to examine these risks, understand what is produced and how it is produced, and the best way to store this material. (NUR15)

If the manager draws up a plan to manage these risks based on our reality, all these risks will be reduced. (NUR06)

\section{DISCUSSION}

Nursing professionals who develop activities in primary health care consider themselves one of the main waste producers in healthcare services. Despite the capacity to recognize the problem and include themselves as fundamental agents in the process, their mistaken practices related to the management of the main waste items in this care modality, in addition to certain training, working, and socioeconomic variables (age), influence the professional knowledge on the matter, making nurses and other healthcare workers susceptible to occupational accidents.

Ideally, the steps of HCW management should follow the specific Brazilian law on the subject $(306 / 04)^{(14)}$ which, although has come into force for ten years, does not address the specificities of waste management in primary health care, especially that originated by home care.

Usually BHUs are set in common buildings which were not designed for healthcare purposes. These units are often located in the outskirts of municipalities to facilitate the access of the population. However, these places do not have proper facilities, which favor waste management, such as: places to store material by groups, internal circulation areas that allow the transit of vehicles to transport waste, and external storage installations ${ }^{(15)}$, in accordance with the reports examined in the present study.

The absence of a specific legislation for HCW management in primary health care, or at least adaptations in the current law which help meet the dynamics of this care modality, is one of the management factors that hinder HCW management in this care category. Management is copied from steps pre-defined and designed for hospital care ${ }^{(1,7)}$, in which HCW management is based on a series of phases (separation, packaging, transportation, storage, and treatment). The first one is considered fundamental and must occur by the producer when waste is generated ${ }^{(4,14)}$.

Flaws in the separation process have consequences in subsequent steps of HCW management, given that in this phase $\mathrm{HCW}$ is separated in the place and time of its generation based on chemical, biological, and physical characteristics, and its physical state and risk potential ${ }^{(16-17)}$.

The main consequence of inadequate practices is occupational accidents. Their incidence is related mostly to sharps and potentially contaminated infectious agents resulting from inadequate HCW management in at least one step of the process, whether inside the institution or during transportation, treatment, and final disposal. Additionally, the lack of security for employees who perform public waste collection is an issue that deserves attention ${ }^{(1,5,18-19)}$.

Characterizing waste is fundamental to manage HCW efficiently, because this procedure allows to identify to which group the items belong, and consequently how they should be packed. As demonstrated by the present study, nursing professionals have difficulties 
to identify in which group the items should be included and the correct place to keep them. This deficiency may lead to mistakes in HCW management and increase the chances of occupational accidents involving healthcare professionals and employees responsible for the external collection of waste ${ }^{(20)}$.

The findings show that healthcare professionals must incorporate HCW management into their daily practice. To achieve this goal it is necessary to reinforce the knowledge of these professionals and create tools to monitor practices related to HCW management ${ }^{(21)}$.

As emphasized by the present study, some socioeconomic and training variables may influence the knowledge and consequently the practice of these professionals. These variables are: time since graduation, length of experience, and age. Other investigations $^{(22-23)}$ showed that over the years some workers rely on their established knowledge, skills, experience, and time of work in the institution to not participate in continuing education activities, which hinders the upgrading demanded by new recommendations. In some cases, the mistake takes form as negligence to apply standard caution measures.

An investigation carried out in $\mathrm{Brazi}^{(7)}$ suggests monitoring HCW management through an indicator which correlates the quantity of infectious waste produced with the number of procedures implemented in critical areas. The goal is to develop a more significant criterion in terms of prevention of environmental and occupational risks capable to elucidate how the separation of infectious waste was performed.

The responsibility of nursing professionals in this stage of $\mathrm{HCW}$ management should be stressed, because they are the members of healthcare teams with the greatest participation in the production and disposal of waste, and thus are the focus of attention and investments in activities related to HCW management ${ }^{(20)}$.

\section{Study limitations}

The present investigation has some limitations. Because it is a cross-sectional study, it does not allow a reliable time analysis of the knowledge of professionals. In addition, the findings would be better supported if there were an observational step designed to examine the production and all of the management stages of the originated waste. Other studies with this design are necessary to substantiate more comprehensive conclusions.

Contributions to the nursing, health or public policy fields

The results of this study point to the need to invest in the continuous education of professionals who work in primary health care, notably those who implement waste-related public policies in environments where outpatient care is offered.

\section{CONCLUSION}

The knowledge of professionals falls short of expectations to carry out an adequate HCW management and is excessively concentrated on the initial steps, mainly disposal. Some socioeconomic (age) and training (time since graduation and length of experience) variables may influence the knowledge and practice of these professionals. Despite these problems, the interviewed employees see themselves as some of the main producers of waste in primary health care. Mistaken practices related to the handling of the main types of waste in the clinical practice of this care modality make nursing professionals and other workers vulnerable to accidents.

It is also noteworthy the need to develop studies investigating other professional categories such as dental teams, which stands out in the production of waste in the primary health care context together with nursing teams.

\section{REFERENCES}

1. Moreira AMM, Günther WMR. Gestión de residuos sólidos en las unidades básicas de salud: aplicación de instrumento facilitador. Rev Latino-Am Enfermagem[Internet]. 2016[cited 2017 Nov 21];(24):e2768. Available from: http://dx.doi.org/10.1590/1518-8345.0646.2768

2. Moreschi C, Rempel C, Backes DS, Carreno I, Siqueira DF, Marina B. A importância dos resíduos de serviços de saúde para docentes, discentes e egressos da área da saúde. Rev Gaúcha Enferm[Internet]. 2014[cited 2017 Nov 21];35(2):20-6. Available from: http:// www.seer.ufrgs.br/RevistaGauchadeEnfermagem/article/view/43998

3. Caniato M, Tudor T, Vaccari M. International governance structures for health-care waste management: a systematic review of scientific literature. J Environ Manag[Internet]. 2015[cited 2017 Nov 21];153:93-107. Available from: http://www.sciencedirect. com/science/article/pii/S0301479715000559

4. Brasil. Lei no 12.305, de 2 de agosto de 2010. Institui a Política Nacional de Resíduos Sólidos; altera a Lei no 9.605 , de 12 de fevereiro de 1998; e dá outras providências[Internet]. Diário Oficial da República Federativa do Brasil, Brasília, 03 agosto 2010 [cited 2017 Nov 21]. Seção 1:1. Available from: http://www.mma.gov.br/estruturas/253/_arquivos/125_publicacao17052011041349_253.pdf

5. Gupta NK, Shukla M, Tyagi S. Knowledge, attitude and practices of biomedical waste management among health care personnel in selected primary health care centres in Lucknow. Int J Community Med Public Health[Internet]. 2017[cited 2017 Nov 21];3(1):30913. Available from: http://www.ijcmph.com/index.php/ijcmph/article/view/697

6. Brasil. Ministério da Saúde. National Record of Healthcare Establishments[Internet]. 2012 [cited 2017 Nov 21]. Available from: http://tabnet.datasus.gov.br/cgi/tabcgi.exe?cnes/cnv/estabbr.def

7. Moreira AM, Günther WM. Assessment of medical waste management at a primary health-care center in São Paulo, Brazil. Waste Manag[Internet]. 2013[cited 2017 Nov 21];33(1):162-7. Available from: https://doi.org/10.1016/j.wasman.2012.09.018

8. Yaghoobi M, Ezzati MH, Ziaee M, Vafaeenejad R, Bakhtiari G, Mostafavi I, et al. Needlestick injuries in healthcare workers in the North East of Iran. Patient Saf Qual Improv[Internet]. 2017[cited 2017 Nov 21];5(2):509-12. Available from: http://psj.mums.ac.ir/ 
article_8543.html

9. Santos JLG, Erdmann AL, Meirelles BHS, Lanzoni GMM, Cunha VP, Ross R. Integração entre dados quantitativos e qualitativos em uma pesquisa de métodos mistos. Texto Contexto Enferm[Internet]. 2017[cited 2017 Nov 21];26(3):e1590016. Available from: http://www.scielo.br/pdf/tce/v26n3/en_0104-0707-tce-26-03-e1590016.pdf

10. Sousa AFL, Queiroz AAFLN, Oliveira LB, Moura MEB, Batista OMA, Andrade D. Social representations of biosecurity in nursing: occupational health and preventive care. Rev Bras Enferm[Internet]. 2016[cited 2017 Nov 21];69(5):810-7. Available from: http:// dx.doi.org/10.1590/0034-7167-2015-0114

11. Mendes WC, Figueiredo MLF, Salmito MA, Araújo EC, Araújo TME. Knowledge and practice of workers, professionals and managers on waste of health services. Rev Pesqui: Cuid Fundam[Internet]. 2015[cited 2017 Nov 21];7(4):3216-26. Available from:http:// www.seer.unirio.br/index.php/cuidadofundamental/article/view/3684

12. Sousa AFL, Queiroz AAFLN, Oliveira LB, Valle ARMC, Moura MEB. Social representations of community-acquired infection by primary care professionals. Acta Paul Enferm[Internet]. 2015[cited 2017 Nov 21];28(5):454-9. Available from: http://dx.doi. org/10.1590/1982-0194201500076

13. Reinert M. Une methode de classification descendante hierarchique: application a I'analyse lexicale par contexte. Cah Anal Donnees[Internet]. 1983[cited 2017 Nov 21];8(2):187-98. Available from: http://www.numdam.org/article/CAD_1983_8_2_187_0.pdf

14. Brasil. Ministério da Saúde. Agência Nacional de Vigilância Sanitária. Manual de gerenciamento de resíduos de serviços de saúde. Brasília (DF): Ministério da Saúde; 2006.

15. Alves SB, Souza ACS, Tipple AFV, Resende KCAD, Resende FR, Rodrigues EG, et al. The reality of waste management in primary health care units in Brazil. Waste Manag Res[Internet]. 2014[cited 2017 Nov 21];32(9):40-7. Available from: https://doi. org/10.1177/0734242X14543815

16. Taghipour H, Alizadeh M, Dehghanzadeh R, Farshchian MR, Ganbari M, Shakerkhatibi M. Performance of on-site Medical waste disinfection equipment in hospitals of Tabriz, Iran. Health Promot Perspect[Internet]. 2016[cited 2017 Nov 21];6(4):202-6. Available from:https://www.ncbi.nlm.nih.gov/pmc/articles/PMC5071788/

17. Kontogianni ST, Moussiopoulos N. Investigation of the occupational health and safety conditions in Hellenic solid waste management facilities and assessment of the in-situ hazard level. Safety Sci[Internet]. 2017[cited 2017 Nov 21];(96):192-7. Available from: https:// doi.org/10.1016/j.ssci.2017.03.025

18. Sathe S, Kagal A, Nagargoje S. A study to assess the effects of planned teaching on the knowledge of auxillary nurse midwifes regarding bio-medical waste management in PHCS in Thane district. J Patient Saf Infec Control[Internet]. 2015 [cited 2017 Nov 21];3(2):28-35. Available from: https://doi.org/10.1016/j.jpsic.2015.10.066

19. Arab M, Safari H, Zandian H, Nodeh FH. Evaluation of practicing safety features for hospital waste collection among Iran's public hospitals. J Mater Cycles Waste Manag[Internet]. 2017[cited 2017 Nov 21];19(2):939-45. Available from: https://doi.org/10.1007/ s10163-016-0496-x

20. Santos MA, Souza AO. [Knowledge of nurses of the Family Health Strategy on health services waste]. Rev Bras Enferm[Internet]. 2012[cited 2017 Nov 21];65(4):645-52. Available from: http://www.redalyc.org/html/2670/267024790014/ Portuguese

21. Pereira MS, Alves SB, Souza ACS, Tipple AFV, Rezende FR, Rodrigues EG. Waste management in non-hospital emergency units. Rev Latino-Am Enfermagem[Internet]. 2013[cited 2017 Nov 21];(21):259-66. Available from: http://dx.doi.org/10.1590/ S0104-11692013000700032

22. Rodrigues PS, Sousa AFL, Magro MCS, Andrade D, Hermann PRS. Occupational accidents among nursing professionals working in critical units of an emergency service. Esc Anna Nery[Internet]. 2017[cited 2017 Nov 21];21(2):e20170040. Available from: http://dx.doi.org/10.5935/1414-8145.20170040

23. Batista OMA, Moura MEB, Sousa AFL, Andrade D. Risco ocupacional entre profissionais de enfermagem de setores críticos e adesão a precaução padrão. Rev Cubana Enferm[Internet]. 2017[cited 2017 Nov 21];33(3). Available from: http://revenfermeria. sld.cu/index.php/enf/article/view/1169 